\title{
Effect of water and resource saving technologies of cotton growing on cotton yield
}

\author{
Sabirjan Isaev 1,*, Sayidjakhon Khasanov ${ }^{1,2,3,4}$, Yusufboy Ashirov ${ }^{2}$, Tokhtakhon Karabaeva ${ }^{2}$, \\ and Azim Gofirov ${ }^{2}$ \\ ${ }^{1}$ Tashkent Institute of Irrigation and Agricultural Mechanization Engineers, Kary Niyazi str., 39, \\ Tashkent, Uzbekistan, 100000 \\ ${ }^{2}$ Tashkent State Agrarian University, University str., 2, Tashkent province, Uzbekistan, 100140 \\ ${ }^{3}$ Institute of Geographical Sciences and Natural Resources Research, Chinese Academy of Sciences, \\ Datun Road, 11A, Beijing, China, 100101 \\ ${ }^{4}$ University of Chinese Academy of Sciences, Yuquan Road, 19A, Beijing, China, 100049
}

\begin{abstract}
In this article, in the conditions of light gray soils of Andijan-37 and Sultan varieties of cotton, before additional application of mineral fertilizers (every 3 years) $6,000 \mathrm{~kg}$ of bentonite per hectare is cultivated with Andijan-37 variety of 1,000 seeds weighing 2-3 g/ha, fiber yield $0,7 \%$, increase in cotton yield by $3.0-3.5 \mathrm{q} / \mathrm{ha}$, in the Sultan variety of cotton the weight of 1000 seeds by $5 \mathrm{~g}$, fiber yield by $1.4 \%$, cotton yield by 4.1-4.5 $\mathrm{q} /$ ha observed an increase in Due to the early ripening of the cotton crop 7-10 days and its $90-100 \%$ compliance with the requirements of the first industrial variety, saving $20-25 \%$ of available resources, the net profit per hectare is $150-105-75 \mathrm{~kg} / \mathrm{ha}$ of mineral fertilizers used in the Sultan variety of cotton. There is information that in comparison with the usual technology fed on norms increased by 192,197 and 553,113 UZS, cotton of Andijan-37 variety increased by 468,048 and 553,148 UZS.
\end{abstract}

\section{Introduction}

Today, the world's irrigated land is 299,488 million hectares. e. World agriculture uses 2.8 thousand $\mathrm{km} 3$ of fresh water per year. It accounts for $70 \%$ of the world's freshwater consumption, 7 times more than the water used by world industry [1, 2, 10-13]. Almost all of this water is used to irrigate crops. Globally, $40 \%$ of food and $60 \%$ of cereals come from irrigated land. In many parts of the world, water supply to agricultural crops is becoming increasingly difficult due to climate change, global warming and declining rainfall. In addition, research that serves the scientific use of existing agrominerals in nature is a topical issue [2, 4-6].

Proper use of available internal resources in raising the level of crops in the republic's agriculture to the required level, increasing soil fertility, scientifically studying the terms and standards of effective use of water-bearing agro-fields to meet the water needs of plants, local application, abundant and high-quality, cheap cotton, the development of new

${ }^{*}$ Corresponding author: sabirjan.isaev@mail.ru 
resource-efficient agro-technologies that ensure the cultivation of competitive, world-class cotton, is one of the pressing issues [1-3].

Taking into account the soil and climatic conditions of the republic, many scientists, including K. Mirzajonov, A. Avliyokulov, N. Ibragimov, tested the newly created cotton varieties in each soil and climatic conditions and developed agrotechnics for growing more and better cotton. A. Urazmatov, Sh. Nurmatov, M. Khamidov, G. Bezborodov, S. Buriev, M. Tojiev, L. Slesareva, R. Nazarov, A. Isashov, A. Shamsiev, S. Isaev, D. Tungushova and other scientists comprehensive scientific research has been conducted [7-14]. However, in the conditions of light gray soils of Andijan province, insufficient research has been conducted to create a scientific and practical basis for the use of non-traditional agro-ores (bentonite) in the cultivation of early, high-quality cotton from Andijan-37 and Sultan varieties of medium-fiber cotton [15-17].

Therefore, the main purpose of the study is to develop technologies for the use of nontraditional bentonite to save water consumption and mineral fertilizers in the cultivation of new medium-fiber cotton Andijan-37 and Sultan varieties of cotton, depending on the irrigation regime in light gray soils of Andijan province.

\section{Materials and methods}

The object of research is light gray soils of Altinkul administrative district in Andijan province (Uzbekistan), norms of mineral fertilizers, bentonite, irrigation regimes, Andijan37 and Sultan varieties of cotton (see red province in Figure 1).

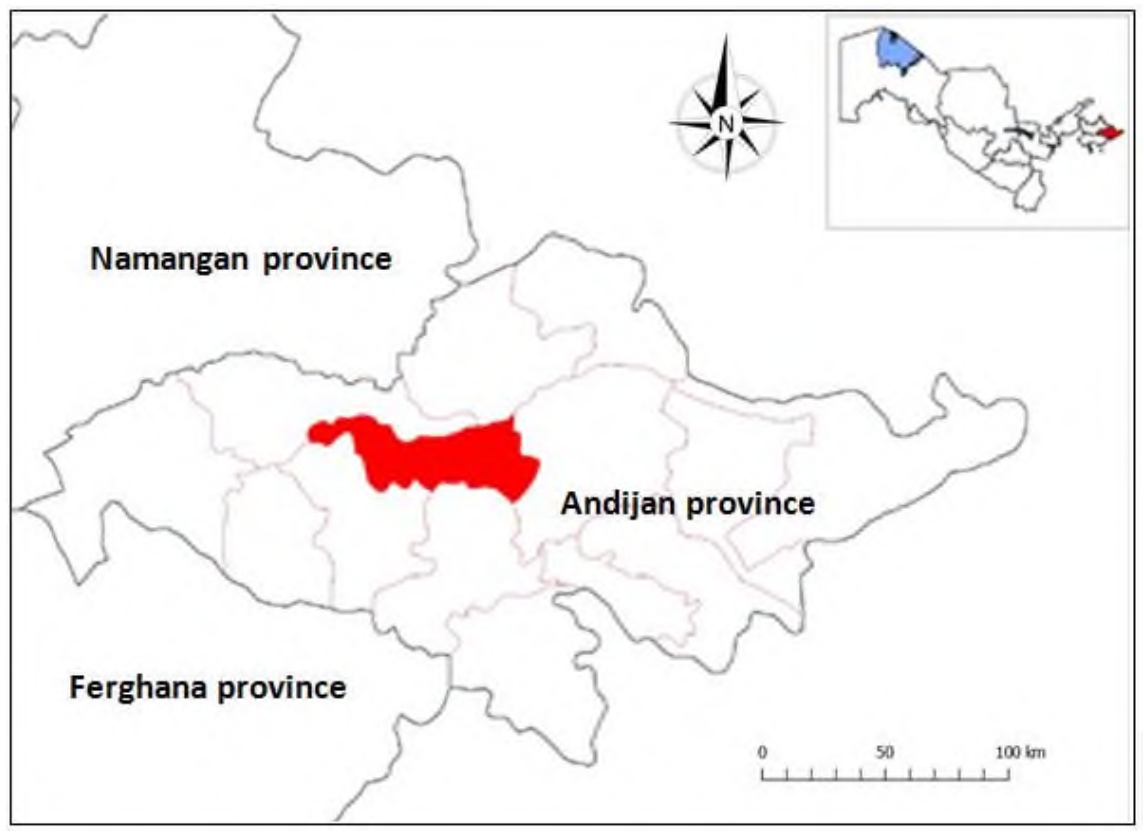

Fig. 1. Map of the study area

The subject of research is the rate of mineral fertilizers, non-traditional bentonite efficiency, irrigation methods, agrophysical properties of soil, agrochemical properties and plant growth, development, yield, fiber quality indicators and economic efficiency. 
Field and laboratory researches "Methods of conducting experiments in cotton growing" [4], "Analysis of agrochemical properties of soil and plants" [5], "Analysis of agrophysical properties of soil" [5, 6], "Methods of conducting field experiments" [7], based on the manuals. During the agrochemical analysis, envelope-shaped soil sections of 1-1.5 m were dug in the experimental field. the amount of mobile phosphorus was determined by the BP Machigin method, the bulk mass of the soil (SN Rijov) was determined by the cylindrical method, the structure was determined by the IV Savvinov method [8-13].

\section{Results and discussion}

The soil-climatic conditions of the study area and research methods are given. The experimental field soils have long been irrigated, light gray soil, medium sand mechanical composition, ancient irrigated, non-saline, groundwater level is 4-5 meters above the ground, annual precipitation is $225 \mathrm{~mm}$, the air temperature is in the Fergana Valley. The beginning of the period is the end of March, when the average daily temperature above $10^{\circ} \mathrm{C}$ is $202-222$ days, the sum of effective temperatures is $1,962-2,555^{\circ} \mathrm{C}$, and the average daily temperature in the desert zone during the period of operation is $23.5^{\circ} \mathrm{C}$ light gray soils 21.6-22,6 and $20.4-21.6^{\circ} \mathrm{C}$ in typical gray soils, frost-free days lasting from 194-214 days, effective temperature sum from April 1 to October 1 to $2,027-2,620^{\circ} \mathrm{C}$, average annual rainfall is typical gray $350 \mathrm{~mm}$ in soils, $240 \mathrm{~mm}$ in light gray soils and up to $100 \mathrm{~mm}$ in desert areas [18-22].

Prior to the experiment in light gray soils, the initial agrochemical properties were described: $0.790 \%$ in $0-30 \mathrm{~cm}$ layer with humus, total nitrogen $0.084 \%$, total phosphorus $0.142 \%, \mathrm{~N}^{-\mathrm{NO}_{3}}$ in mobile form $18.8 \mathrm{mg} / \mathrm{kg}$, mobile phosphorus $28.1 \mathrm{mg} / \mathrm{kg}$ and exchangeable potassium $200 \mathrm{mg} / \mathrm{kg}$ were found to be low in nutrients.

In the experimental years, Andijan-37 and Sultan varieties of cotton were fed with mineral fertilizers at the rate of NPK-150-125-75 kg/ha, $750 \mathrm{~kg}$ of bentonite was applied during the cotton mowing period, and $70-70-60 \%$ of cotton varieties were irrigated with the limited field moisture capacity (LFMC). As a result of the positive properties of bentonite, the amount of nutrients in the general form in the $0-30 \mathrm{~cm}$ layer of soil increased by $8-10 \%$ compared to control options, the amount of mobile nutrients by $10-15 \%$, mineral fertilizers by $25 \%$ less than $6,000 \mathrm{~kg} / \mathrm{ha}$ bentonite In the case of irrigated varieties with additional irrigation and cotton varieties $70-70-60 \%$ of the soil LFMC, the amount of nutrients in the general form in the $0-30 \mathrm{~cm}$ layer of soil is $12-15 \%$ compared to the control options, the amount of mobile nutrients is $32-40 \%$ increase was detected.

In experiments on light gray soils of Andijan province, the soil mass was reduced with mineral fertilizers and $6,000 \mathrm{~kg}$ of bentonite per hectare was applied before plowing (every 3 years), although the soil layer was compacted to $0.08 \mathrm{~g} / \mathrm{cm}^{3}$ per head during the application period, a decrease of $0.12-0.13 \mathrm{~g} / \mathrm{cm}^{3}$ was observed in a relatively average 3 years (Figure 2). 


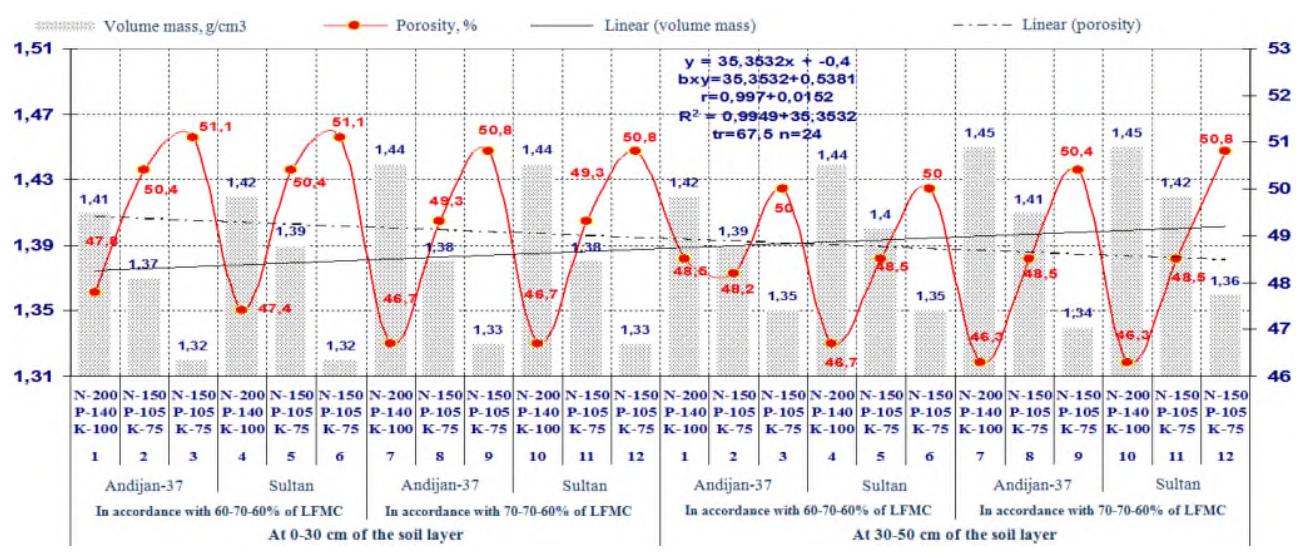

Fig. 2. Changes in soil volume, mass and porosity of the experimental field, 2015

Note: 6.0 tons per hectare (once in 3 years) was fed to 3, 6, 9 and 12 options before cultivation, and $750 \mathrm{~kg} / \mathrm{ha}$ of bentonite was fed to 2, 5, 8 and 11 options annually during mowing.

Similar patterns were observed in the variants of both cotton varieties with $6,000 \mathrm{~kg}$ of bentonite per hectare before plowing (once in 3 years) with an average porosity of 52.2 and $53.3 \%$ at the beginning of the application period, and by the end of the application period the soil porosity was positive. Decreased by $2.5 \%(50.8 \%)$. In the control variants, it was observed that the soil porosity decreased by $4.8 \%$ compared to the bentonite variants.

Soil water permeability In light gray soils, cotton varieties were fed at the rate of mineral fertilizers NPK-150-105-75 kg/ha during the period of cotton weeding with the addition of $750 \mathrm{~kg}$ of bentonite per hectare and 6,000 kg per hectare (once in 3 years), soil LFMC 70-70-60\% were observed to be good in these options, with an average of 691.9 and 674.9 per hectare for three hours at the beginning of the application period, respectively; Although the water absorption was accounted for 681.1 and $677.9 \mathrm{~m}^{3} / \mathrm{ha}$ in the beginning, the water absorption at the end of the application period was $15.6 \mathrm{~m}^{3}$ per minute, with low rates of mineral fertilizers applied and results close to those of the additional $6,000 \mathrm{~kg}$ bentonite variants. In the control variants, the water permeability of the soil decreased by the end of the application period, and in the variants fed mineral fertilizers NPK-200-140-100 kg/ha of cotton varieties, the water permeability of the soil for 6 hours compared to the beginning of the application period was $184.3-221.4 \mathrm{~m}^{3} / \mathrm{ha}$. decreased to $442.9-464.9 \mathrm{~m}^{3} / \mathrm{ha}$. It was found that the water permeability of these variants decreased by $70-100 \mathrm{~m}^{3} /$ ha compared to the bentonite variants.

In the experiments, irrigation procedures and mineral fertilizers NPK-150-105-75 kg/ha, fertilization of Andijan-37 and Sultan cotton varieties, application of $750 \mathrm{~kg}$ of bentonite per hectare between rows in the cotton mowing phase and an additional $6000 \mathrm{~kg}$ of phosphorus and potassium fertilizers before driving In the bentonite-laden variants, cotton played an important role in the longer retention of soil moisture between rows, in the growth and development of cotton.

$6,000 \mathrm{~kg}$ of bentonite per hectare was applied before driving to a reduced rate of $25 \%$ of mineral fertilizers, and cotton varieties irrigated in the order of $70-70-60 \%$ of the soil relative to LFMC showed that the most effective measure of long-term retention of soil moisture. Evaporation of soil moisture due to a significant improvement in soil density and porosity, as well as water permeability properties of $6,000 \mathrm{~kg}$ of bentonite per hectare planted before the autumn plowing, 2.0-2.5 times compared to control options NPK 200$140-100 \mathrm{~kg} / \mathrm{ha}$ per hectare of mineral fertilizers decreased. As a result, this option also 
extended irrigation periods due to longer soil moisture retention. Cotton varieties were fertilized with NPK $150-105-75 \mathrm{~kg} / \mathrm{ha}$ at the rate of NPK $150-105-75 \mathrm{~kg} / \mathrm{ha}$ and $6,000 \mathrm{~kg} / \mathrm{ha}$ bentonite before plowing and irrigated at $70-70-60 \%$ soil moisture relative to LFMC. was higher than the options under normal fertilized soil conditions and was an important factor in the long retention of soil moisture and a significant reduction in the number of irrigations during the application period.

Soil moisture and irrigation standards differ from other options in the case of bentonite application at the rate of $6000 \mathrm{~kg}$ per hectare before driving using mineral fertilizers (in 2015 conditions) NPK-150-105-75 kg/ha, the effect of bentonite in the soil composition at $0-100 \mathrm{~cm}$ layer is long continued, the humidity was at its highest level compared to other options. As a result, it was possible to drastically reduce water consumption in both irrigation regimes during irrigation of cotton varieties during the growing season.

$60-70-60 \%$ of the soil was irrigated in the order of $60-70-60 \%$ between 27 and 28 days, with an average water consumption of $771 \mathrm{~m}^{3} /$ ha and a total of $2,312 \mathrm{~m}^{3} /$ ha 3 times during the season. This means that the number of irrigations of cotton varieties has been reduced by two, saving $2,051 \mathrm{~m}^{3} /$ ha of water consumption compared to the control option in this irrigation scheme. Also, in the order of irrigation of $70-70-60 \%$ of the soil relative to LFMC, cotton was irrigated 4 times between 26 and 28 days, at an average irrigation rate of $707 \mathrm{~m}^{3} / \mathrm{ha}$. A total of $2,827 \mathrm{~m}^{3} / \mathrm{ha}$ of water was supplied during the season. This means that even in this irrigation mode, water consumption is reduced or saved by $2,060 \mathrm{~m}^{3} / \mathrm{ha}$ compared to the control option. In short, even in this irrigation scheme, the number of irrigations of cotton varieties has halved.

As a result of the positive effect of $6,000 \mathrm{~kg}$ of bentonite applied to the soil during the entire application period, the irrigation interval was extended to 10-13 days, and cotton varieties were watered for 26-28 days. Considering the differences in the methods of interaction of bentonite variants, the evaporation of soil moisture in $60-70-60 \%$ of irrigated variants compared to LFMC is $0.96-1.0 \%$ per day, in $70-70-60 \%$ of irrigated variants evaporation was $0.40-0.44 \%$, and $60-70-60 \%$ of the soil was observed to evaporate under the positive effect of bentonite compared to $60-70-60 \%$ irrigation regime options.

According to the calculation of the amount of water consumed in the experimental variants, in the variants irrigated at a soil moisture content of $60-70-60 \%$ relative to the soil LFMC, the combined control of common mineral fertilizers NPK $200-140-100 \mathrm{~kg} / \mathrm{ha}$ for a total of 3 years in total combined with reserve water and rainwater $4,972 \mathrm{~m}^{3} / \mathrm{ha}$ in the variants, the amount of water consumed in the variants irrigated in the order of $70-70-60 \%$ of the soil relative to the LFMC was $5,677 \mathrm{~m}^{3} / \mathrm{ha}$.

Mineral fertilizers NPK $150-105-75 \mathrm{~kg} / \mathrm{ha}$ were fertilized with $750 \mathrm{~kg} / \mathrm{ha}$ of bentonite between rows during the cotton mowing period, and $60-70-60 \%$ of the irrigated variants were combined with reserve water and rainwater for a total of $3,653 \mathrm{~m}^{3} /$ ha, the amount of water consumed in the irrigated variants at 70-70-60\% soil moisture compared to LFMC was $4,950 \mathrm{~m}^{3} / \mathrm{ha}$. Before driving, mineral fertilizers NPK $150-105-75 \mathrm{~kg} / \mathrm{ha}$ with an additional $6,000 \mathrm{~kg}$ of bentonite and $60-70-60 \%$ of the variants irrigated in the order of 60 $70-60 \%$, combined with reserve water and rainwater, a total of $3,473 \mathrm{~m}^{3} / \mathrm{ha}$, compared to LFMC. The amount of water consumed in the irrigated variants at $70-70-60 \%$ soil moisture was $3,911 \mathrm{~m}^{3} / \mathrm{ha}$ (Figure 3 ). 

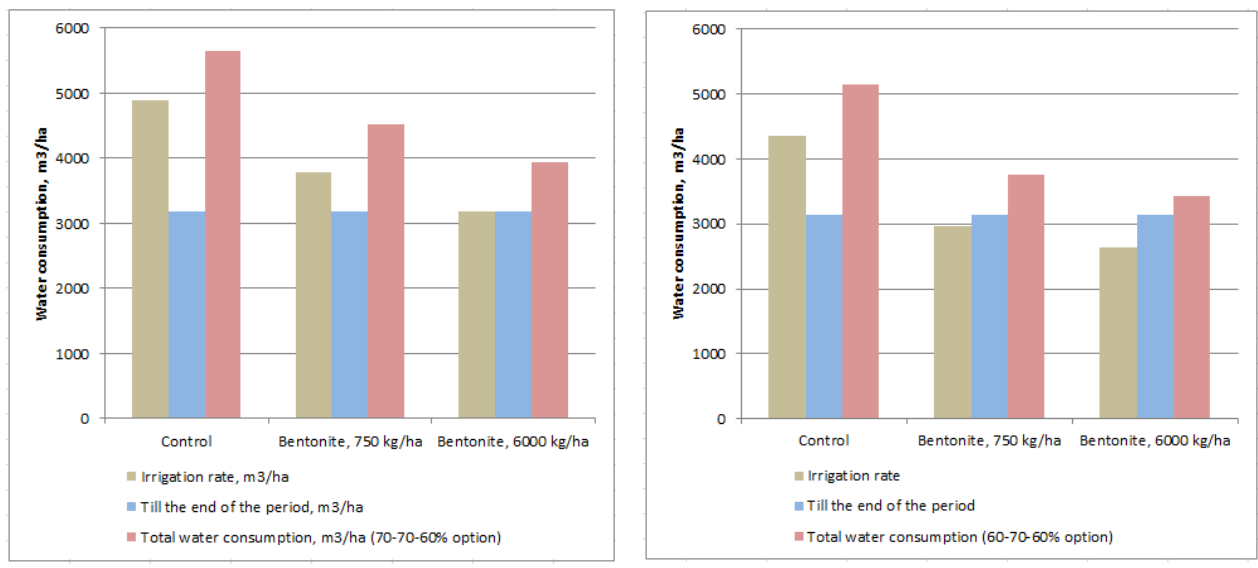

Fig. 3. Average water consumption by experimental field options, 2015

According to the results of the study, mineral fertilizers NPK $150-105-75 \mathrm{~kg} / \mathrm{ha}$ were fed by adding $750 \mathrm{~kg} / \mathrm{ha}$ of bentonite between rows during the cotton ginning period and $1,319 \mathrm{~m}^{3}$ compared to the control variant due to the effect of bentonite in $60-70-60 \%$ irrigation mode compared to LFMC, and in the order of 70-70-60\% irrigation compared to LFMC, $727 \mathrm{~m}^{3} /$ ha of water was saved in irrigated variants.

Due to the effect of bentonite in the variants reduced by $25 \%$ of mineral fertilizers and added an additional $6,000 \mathrm{~kg} / \mathrm{ha}$ of bentonite before irrigation and irrigated in the order of $60-70-60 \%$ in relation to LFMC, $1499 \mathrm{~m}^{3} / \mathrm{ha}$, in the variants irrigated in the order of $70-70$ $60 \%$ in relation to LFMC $1,776 \mathrm{~m}^{3} /$ ha of water savings.

When calculating the saved water according to the consumption of cotton varieties, it was found that the mineral fertilizers of Andijan-37 variety of cotton irrigated at $60-70-60 \%$ soil moisture relative to LFMC NPK $150-105-75 \mathrm{~kg} / \mathrm{ha}$ at the rate of $750 \mathrm{~kg} / \mathrm{ha}$ between cotton rows When fertilized with bentonite and added 2.4 quintals of cotton compared to the control option, the water consumption for 1 quintal of cotton was $99.5 \mathrm{~m}^{3} / \mathrm{ha}$, and the water consumption was $45.9 \mathrm{~m}^{3}$, although the yield of cotton increased compared to the control option. / was found to decrease. In the Sultan variety of cotton, a total of $3,653 \mathrm{~m}^{3}$ of water was used to grow $37.1 \mathrm{t} /$ ha of cotton, $98.5 \mathrm{~m}^{3} /$ ha of water was used for 1 quintal of cotton, or $47.7 \mathrm{~m}^{3} /$ ha less than in the control option.

In addition, $6,000 \mathrm{~kg}$ of bentonite was applied before additional driving using NPK 150$105-75 \mathrm{~kg} / \mathrm{ha}$ norms of mineral fertilizers and 3 quintals of additional yield was harvested compared to the control option when irrigated in $60-70-60 \%$ irrigation mode compared to LFMC.

In the experiment, the water consumption for the production of 1 ton of cotton in Andijan-37 variety of cotton in the order of irrigation of $70-70-60 \%$ of the soil relative to LFMC was $93.1 \mathrm{~m}^{3} / \mathrm{ha}$, although the cotton yield increased compared to the control option, water consumption was $52.3 \mathrm{~m}^{3}$ was found to decrease. In the Sultan variety of cotton, 37.4 $\mathrm{q} /$ ha of cotton was grown, $92.9 \mathrm{~m}^{3} /$ ha of water was used for 1 quintal of harvest, which is $53.3 \mathrm{~m}^{3} /$ ha less than in the control variant (Figure 4).

According to the results of a three-year study, in addition to the reduced standards of mineral fertilizers before driving in the agro-techniques of Andijan-37 and Sultan varieties of cotton $6-7 \mathrm{~kg} / \mathrm{ha}$ of bentonite soil is suitable for irrigation in the order of $70-70-60 \%$ or 1-2-1 irrigation system was found to be a mineral fertilizer and water-saving agronomic measure. 


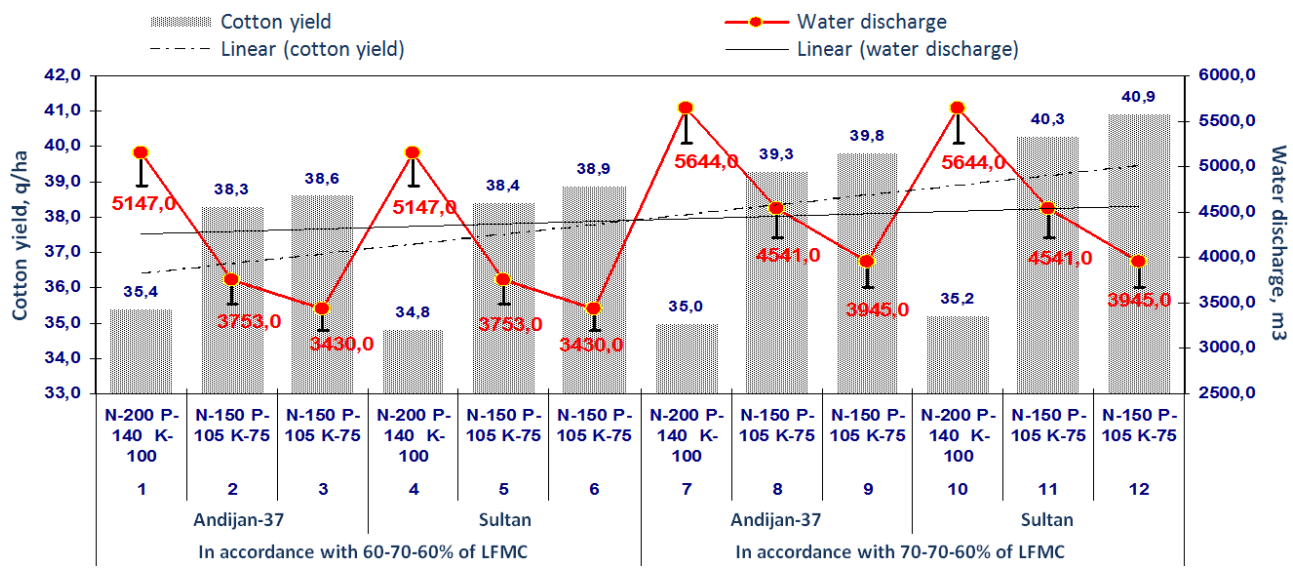

Fig. 4. Amount of water used for cotton yield obtained by experimental options

Before driving, the annual norms of mineral fertilizers were reduced by $25 \%$ and 6,000 $\mathrm{kg}$ of bentonite per hectare was applied before the autumn plowing, 7 and 14.5 units of yield elements, 6.8 and 8.3 units of stalks were formed, and in comparison with its control variant, the yield of Andijan-37 variety increased by 1.9 units, yield elements and stalks increased by 2.0 units. It was observed an increase of 2.3 units, yield elements and pods by 2.2 units.

For the first time in the experiment, cotton was fed with NPK $150-105-75 \mathrm{~kg} / \mathrm{ha}$ fertilizer at the rate of $750 \mathrm{~kg}$ of bentonite per hectare and $6,000 \mathrm{~kg}$ of bentonite per hectare at the pre-driving mineral fertilizer rate. enriched with substances, creating optimal soil conditions with high fertility. Also, agro-measures fed with the addition of $750 \mathrm{~kg}$ of bentonite per hectare at the rate of NPK $150-105-75 \mathrm{~kg} / \mathrm{ha}$ during the period of cotton weeding showed that it is possible to grow high cotton yields, increasing the efficiency of mineral fertilizers by $50-60 \%$.

According to the results of the experiment, under the influence of agronomic measures applied to cotton varieties and irrigation regimes of $70-70-60 \%$ of the soil LFMC, Andijan37 and Sultan cotton varieties yielded 5.6-5.7 cotton varieties per irrigation and irrigation regimes, respectively. At the same time, regardless of the norms of bentonite and the duration of application, almost no difference was observed, or in both varieties of cotton formed a single cocoon weighing 0.2-0.3 g more than the control options.

Cotton yield of cotton varieties studied in the experiment was $38.4 \mathrm{~kg}$ of Andijan-37 cotton and $39.4 \mathrm{t} / \mathrm{ha}$ of Sultan cotton in the variants with bentonite at the rate of $6,000 \mathrm{~kg}$ per hectare before application with mineral fertilizers NPK $150-105-75 \mathrm{~kg} / \mathrm{ha}$. Conventional mineral fertilizers NPK 200-140-100 kg/ha yielded 4.0 and $4.6 \mathrm{q} / \mathrm{ha}$, respectively, compared to the control options fed at the rates. The same patterns were observed in all variants of cotton varieties irrigated in the order of $60-70-60 \%$ of the soil relative to the LFMC, and the yield of cotton decreased by 1.1-2.0 $\mathrm{q} /$ ha compared to the variants of the soil in the order of $70-70-60 \%$ of the LFMC (Table 1). 
Table 1. Cotton yield, q/ha

\begin{tabular}{|c|c|c|c|c|c|c|c|c|c|c|}
\hline \multirow{3}{*}{ 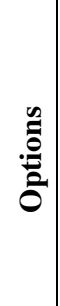 } & \multirow{3}{*}{$\begin{array}{c}\text { Cotton } \\
\text { varieties }\end{array}$} & \multirow{2}{*}{\multicolumn{3}{|c|}{$\begin{array}{c}\text { Annual application } \\
\text { of mineral } \\
\text { fertilizer, } \mathrm{kg} / \mathrm{ha}\end{array}$}} & \multicolumn{4}{|c|}{ Cotton yield, q/ha } & \multicolumn{2}{|c|}{$\begin{array}{c}\text { Additional yield, } \\
\text { q/ha }\end{array}$} \\
\hline & & & & & \multirow{2}{*}{ 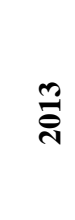 } & \multirow{2}{*}{ 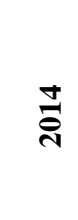 } & \multirow{2}{*}{$\frac{4}{8}$} & \multirow{2}{*}{ 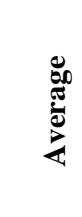 } & \multirow{2}{*}{ 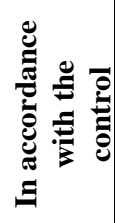 } & \multirow{2}{*}{ 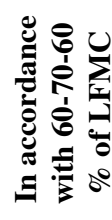 } \\
\hline & & $\mathbf{Z}$ & $\overbrace{}^{n}$ & O્ત & & & & & & \\
\hline 1 & Andijan-37 & 200 & 140 & 100 & 33.9 & 33.5 & 35.4 & 34.3 & - & - \\
\hline 2 & Andijan -37 & 150 & 105 & 75 & 36.1 & 36.2 & 38.3 & 36.7 & 2.4 & - \\
\hline 3 & Andijan -37 & 150 & 105 & 75 & 36.8 & 36.5 & 38.6 & 37.3 & 3.0 & - \\
\hline 4 & Sultan & 200 & 140 & 100 & 34.8 & 32.5 & 34.8 & 34.0 & - & - \\
\hline 5 & Sultan & 150 & 105 & 75 & 37.7 & 35.3 & 38.4 & 37.1 & 3.1 & - \\
\hline 6 & Sultan & 150 & 105 & 75 & 37.9 & 35.4 & 38.9 & 37.4 & 3.4 & - \\
\hline 7 & Andijan-37 & 200 & 140 & 100 & 34.0 & 34.1 & 35.0 & 34.4 & - & 0.1 \\
\hline 8 & Andijan -37 & 150 & 105 & 75 & 37.3 & 36.9 & 39.3 & 37.8 & 3.4 & 1.1 \\
\hline 9 & Andijan -37 & 150 & 105 & 75 & 38.0 & 37.5 & 39.8 & 38.4 & 3.0 & 1.1 \\
\hline 10 & Sultan & 200 & 140 & 100 & 34.8 & 34.3 & 35.2 & 34.8 & - & 0.8 \\
\hline 11 & Sultan & 150 & 105 & 75 & 38.5 & 37.8 & 40.3 & 38.9 & 4.1 & 1.8 \\
\hline 12 & Sultan & 150 & 105 & 75 & 39.0 & 38.3 & 40.9 & 39.4 & 4.6 & 2.0 \\
\hline
\end{tabular}

Note: Mineral fertilizers were fed at the rate of NPK-150-105-75 kg/ha between the rows during the mowing (annually) $750 \mathrm{~kg} / \mathrm{ha}$ and before the autumn plowing (once in 3 years) by adding bentonite $6,000 \mathrm{~kg} / \mathrm{ha}$. Seedling thickness was studied in the range of 90-100 thousand/bush. Options 1-6 are irrigated at a soil moisture content of 60-70-60\% relative to LFMC, options 7-12 are irrigated at 70$70-60 \%$ relative to $L F M C$.

This is because, as mentioned above, in the options of this irrigation regime, in the early stages of cotton, a decrease in nutrients was observed due to incomplete decomposition of minerals in the soil at $60 \%$ soil moisture relative to LFMC. As a result, the growth and development of plants of these variants lagged behind, and the yield of cotton was relatively reduced. The yield of cotton by varieties was irrigated in the order of $70-70-60 \%$ of the soil relative to LFMC, in both variants with bentonite the cotton yield of Sultan cotton was 1.0-1.1 q/ha higher than that of Andijan-37 cotton. At the same time, it had a positive effect on its quality indicators. Although a decrease in cotton yield was observed in all variants irrigated in the order of $60-70-60 \%$ of the soil relative to LFMC, there were no significant differences in the yield of cotton grown by varieties.

It was found that using the elements of agro-technologies used in the experiment, ie bentonite agro-ore, which saves water and mineral fertilizers in the cultivation of cotton, it is possible to grow high-quality cotton from Andijan-37 and Sultan varieties of cotton.

While under the influence of different agro-measures in the experiments, each variant formed a specific cotton yield, according to them, the economic efficiency of each variant also had a certain degree of economic performance. Irrigation of $70-70-60 \%$ of the soil in relation to LFMC consumed an average of $2827 \mathrm{~m} 3 / \mathrm{ha}$ of water in 3 years, fertilized with mineral fertilizers NPK $150-105-75 \mathrm{~kg} / \mathrm{ha}$ at the rate of $750 \mathrm{~kg} / \mathrm{ha}$ bentonite or $6,000 \mathrm{~kg}$ per 
hectare before driving with mineral fertilizers In the bentonite variants, the yield of cotton of the Sultan variety of cotton is 38.9-39.4 q/ha, compared to the control variant fed with conventional mineral fertilizers NPK $200-140-100 \mathrm{~kg} / \mathrm{ha}$ at the rate of 4.1 and $4.6 \mathrm{q} / \mathrm{ha}$. the highest economic return was obtained in the option where additional crops were grown. The gross income from these options amounted to 5,517,304 and 5,588,220 UZS, respectively, with a net profit of $1,176,624$ and $1,537,540$ UZS per hectare. The profitability rates were $27.1 \%$ and $37.9 \%$, respectively, and agro-measures proved to be the most cost-effective measures. The current mineral fertilizers received 192,197 and 553,113 UZS/ha more, respectively, compared to the control option fed at the rate of NPK 200-140$100 \mathrm{~kg} / \mathrm{ha}$. The profitability of the control option was also $24.9 \%$. The cotton yield of Andijan-37 in these variants was 37.8 and $38.4 \mathrm{q} / \mathrm{ha}$, while the gross economic income averaged 5,361,287 and 5,446,387 UZS per hectare for 3 years, respectively. The net profit was $1,633,224$ and $1,718,324 \mathrm{UZS}$, which is 468,048 and $553,148 \mathrm{UZS} /$ ha more than the control option, where the current mineral fertilizers were fed at NPK $200-140-100 \mathrm{~kg} / \mathrm{ha}$. Profitability rates were 29.2 and $36.1 \%$, respectively, with a decrease of 3.0 and $2.8 \%$ compared to Sultan. At the same time, the profitability of the control option was $23.2 \%$. It was found that the use of bentonite agro-ore, which saves water and mineral fertilizers in the cultivation of cotton, is an agro-measure with high economic efficiency in the production of high quality cotton from Andijan-37 and Sultan varieties.

\section{Conclusion}

In the conditions of light gray soils of Andijan province, bentonite from agroma was applied to the cotton row spacing or before plowing.

In Andijan-37 and Sultan varieties of cotton, the annual norms of mineral fertilizers are applied at NPK-150-105-75 kg/ha between $750 \mathrm{~kg}$ per hectare between rows (annually) or $6,000 \mathrm{~kg} / \mathrm{ha}$ during autumn plowing (once in 3 years). when fed with the addition of bentonite, when irrigated in the order of $70-70-60 \%$ relative to LFMC in the soil layer of 030 and $30-50 \mathrm{~cm}$ is compacted to $0.06-0.05 \mathrm{~g} / \mathrm{cm}^{3}$ and $0.08 \mathrm{~g} / \mathrm{cm}^{3}$ compared to the beginning of the application period, Under the positive effect of bentonite, the soil density decreased by $0.06-0.08 \mathrm{~g} / \mathrm{cm}^{3}$ compared to the control option, creating favorable soil conditions for rapid growth and development of plants during the application period.

Cotton varieties are applied in the order of irrigation in the order of 60-70-60 and 70-70$60 \%$ relative to LFMC, mineral fertilizers NPK-150-105-75 kg/ha in the variants of 6,000 $\mathrm{kg} /$ ha bentonite ( 3 and $6 ; 9$ and 12) at the beginning of the period, the water permeability of the soil was the highest compared to the other options, averaging 709.8 and 697.7 per hectare for 6 hours per three years; Absorption of water in the soil in the amount of 71.3.3 and $694.8 \mathrm{~m}^{3} / \mathrm{ha}, 19.3-19.7 \mathrm{~m}^{3}$ per minute, with the positive effect of bentonite mobile nitrogen $42.12-44.36 \mathrm{mg} / \mathrm{kg}$, mobile phosphorus $43.44-46.41 \mathrm{mg} / \mathrm{kg}$, an increase in exchangeable potassium was observed to $200-240 \mathrm{mg} / \mathrm{kg}$.

Mineral fertilizers of Andijan-37 and Sultan varieties of cotton are fed at the rate of NPK-150-105-75 kg/ha (annually) with the addition of $750 \mathrm{~kg}$ of bentonite per hectare and irrigated in the order of $70-70-60 \%$ relative to the LFMC. Although reduced by $\%$, during the mowing and flowering periods of cotton varieties, an increase in mobile nitrogen of 14.22 and 29.99 , mobile phosphorus by 12.65 and $30.18 \mathrm{mg}$, and potassium by 80 and 100 $\mathrm{mg}$, respectively, was observed compared to the leaf period.

NPK 200-140-100 kg/ha of conventional mineral fertilizers irrigated in the order of 70$70-60 \%$ relative to LFMC, evaporation of soil moisture in the control variants per day averaged $0.76-0.82 \%$ for 3 years, while mineral fertilizers NPK at the rate of $6,000 \mathrm{~kg} / \mathrm{ha}$ before driving (once in 3 years) applied at the rate of $150-105-75 \mathrm{~kg} / \mathrm{ha}$, the evaporation of soil moisture decreased by an average of $0.44 \%$ per day. 
In all variants of cotton varieties irrigated in the order of $60-70-60 \%$ relative to the LFMC, the cotton yield decreased by 1.5-2.0 q/ha due to water (soil moisture) compared to the variants in the order of $70-70-60 \%$ irrigation compared to the LFMC. In the variants with $6,000 \mathrm{~kg} / \mathrm{ha}$ of bentonite per hectare (once in 3 years) before additional application of mineral fertilizers to the norm of NPK-150-105-75 kg/ha, the highest yield of cotton from Andijan-37 and Sultan varieties is 38.4 and $39.4 \mathrm{q} / \mathrm{ha}$. The crop is grown.

Irrigation in the order of 70-70-60\% in relation to LFMC consumed an average of 2,827 $\mathrm{m} 3 / \mathrm{ha}$ of water per hectare for 3 years, fertilized by adding $750 \mathrm{~kg} / \mathrm{ha}$ of bentonite between rows (annually) or before driving when mowing mineral fertilizers NPK $150-105-75 \mathrm{~kg} / \mathrm{ha}$ (Once in 3 years) with bentonite variants at the rate of $6,000 \mathrm{~kg} / \mathrm{ha}$, the highest economic income was obtained from the Sultan variety of cotton with 192,197 and 553,113 UZS / ha more than the control variant fed with mineral fertilizers NPK 200-140-100 kg/ha.

Andijan-37 variety of cotton averaged 5,361,287 and 5,446,387 UZS per hectare for 3 years. The net profit was 1,633,224 and 1,718,324 UZS, which is 468,048 and 553,148 UZS more, respectively, compared to the control option of cotton fed with mineral fertilizers NPK 200-140-100 kg/ha. Profitability rates were 29.2 and 36.1\%, respectively, with a decrease of 3.0 and $2.8 \%$ compared to Sultan. At the same time, the profitability of the control option was $23.2 \%$.

In the care of Andijan-37 and Sultan varieties of cotton in light gray soils of Andijan province, the annual rate of mineral fertilizers is set at NPK-150-105-75 kg/ha, taking into account the consumption of bentonite from agroma, between rows during the mating season (annually). It is recommended to add $750 \mathrm{~kg} / \mathrm{ha}$ or $6000 \mathrm{~kg} / \mathrm{ha}$ of bentonite (once in 3 years) to the mineral fertilizers before the autumn drive, and to irrigate at $70-70-60 \%$ relative to LFMC in a 1-2-1 system with a seasonal irrigation rate of $\mathrm{m}^{3} / \mathrm{ha}$.

We thank the head of the Andijan experimental station of the Research Institute of Cotton Breeding, Seed Production and Agrotechnology for the implementation of this research in the framework of the priority direction of the Republican Development of Science and Technology V. "Agriculture, Biotechnology, Ecology and Environmental Protection".

\section{References}

1. Presidential Decree No. 6024 of the Republic of Uzbekistan on "Approval of the Concept of Water Resources Development of the Republic of Uzbekistan for 20202030" on June 10 (2020)

2. Presidential Decree No. 5853 of the Republic of Uzbekistan on "Measures for efficient use of land and water resources in agriculture" on October 23 (2019)

3. Presidential Decree No. 5742 of the Republic of Uzbekistan on "Measures for efficient use of land and water resources in agriculture" on July 17 (2020)

4. Methods of agrochemical, agrophysical and microbiological studies in irrigated lands, 439 (Sharq, Tashkent, 2019)

5. Methods of agro-physical studies, 375 (Sharq, Tashkent, 2013)

6. Methods of agro-chemical analysis of soil and plants, 517 (Sharq, Tashkent, 2017)

7. Methods of conducting field experiments, 148 (Oqituvchi, Tashkent, 2007)

8. Cotton - a reference textbook, 458 (Mehnat Press, Tashkent, 1999)

9. Reference of cotton production, 539 (Science and Technologies Press, Tashkent, 2016)

10. R. Kulmatov, A. Taylakov, S. Khasanov, Envi. Sci. Poll. Research, 1-11 (2021)

11. I. Aslanov, S. Khasanov, Y. Khudaybergenov, M. Groll, CH. Opp, F. Li, E. Ramirez Del-Valle, E3S Web of Conferences 227, 02005 (2021) 
12. N. Teshaev, B. Mamadaliyev, A. Ibragimov, S. Khasanov, InterCarto. InterGIS 26(3), 324-333 (2020)

13. A. Jumanov, S. Khasanov, A. Tabayev, G. Goziev, U. Uzbekov, E. Malikov, In IOP Conference Series: Earth and Environmental Science 614(1), 012150 (2020)

14. Q. Mi, X. Li, X. Li, G. Yu, J. Gao, Agricultural Water Management 224, 106596 (2021)

15. M. A. Imran, A. Ali, M. Ashfaq, S. Hassan, R. Culas, C. Ma, Land Use Policy 88, 104-113 (2019)

16. F. Zulfiqar, A. Datta, G. B. Thapa, Journal of cleaner production 166, 1372-1380 (2017)

17. A. T. Kenjabaev, A. O. Sultonov, AJMR 7(11), 147-151 (2018)

18. SH. Kenjabaev, F. Hans Georg, I. Begmatov, S. Isaev, B. Matyakubov, J. Critical Reviews 7(5), 340-349 (2020)

19. S. Isaev, SH. Mardiev, Z. Qodirov, J. Critical Reviews 7(6), 145-149 (2020)

20. S. Isaev, A. Jumanov, M. Avlakulov, A. Tabaev, E. Malikov, J. Critical Reviews 7(9), 63-71 (2020)

21. S. Isaev, I. Begmatov, G. Goziev, S. Khasanov, In IOP Conference Series: Materials Science and Engineering 883(1), 012080 (2020)

22. S. K. Isaev, R. U. Rakhmonov, S. S. Tadjiev, G. I. Goziev, S. Z. Khasanov, In IOP Conference Series: Earth and Environmental Science 614(1), 012147 (2020) 